At the following meeting of the Seismological Society, Prof. Ewing described an instrument of a similar nature, and only differing from the one described by Mr. Gray in the details of an arrangement for compensating the variable leverage, an arrangement practically adopted by $\mathrm{Mr}$. Gray in the abovementioned torsion pendulum. This seismograph is now distinctly claimed by Prof. Ewing as his own (NATURE, December 23, I886, p. 172)

In June I88I, Mr. Gray suggested several nethods by which a pendulum might be rendered astatic (Trans. Seis. Soc. vol. iii. p. 145). This was followed by Prof. Ewing's device to obtain the same result by an arrangement which was closely foreshadowed by Dr. Wagener, who endeavoured to compensate the movement of a pendulum by a heavy-headed recording index (Trans. Seis. Soc. vol. i. pp. 66 and 67 ).

In addition to the seismographs here referred to, there are many others that might be mentioned. Amongst them we find the parallel-motion instrument of $\mathrm{Mr}$. West, which was immediately followed by parallel-motion instruments the invention of Prof. Ewing and Prof. Alexander (Trans. Seis. Soc. vol. iv. pp. 22 and 30 ).

The development of the parallel-motion instruments may be taken as illustrative of what has happened with regard to nearly all the other seismographs, which in great measure have been gradually developed from something which preceded them.

By improving the bracket seismograph, Prof. Ewing made a considerable advance in seismometry, for which the workers in this country undoubtedly accord him their hearty thanks; but while describing a beautifully constructed, but at the same time inconvenient and obsolete arrangement of seismographs (NATURE, vol. xxx. pp. I49 and 175 , and vol. xxxiv. p. 343), it is hardly fair that his fellow-workers, especially Mr. Gray, the most prolific of earthquake inventors, should be passed by unnoticed, and have their work practically appropriated.

Tokio, February 10

\section{John Milne}

\section{Supposed Suicide of the Cobra}

THE following observations may be of interest as bearing on the reputed suicide of snakes.

Yesterday, while riding over a bare sandy plain I caught sight of a large black cobra moving leisurely along. Having no other weapon with me but a 450 express rifle, I halted my camel and fired, at about 50 yards, just as it was disappearing down a rathole. The bullet passed through the middle of its body without severing the spine; the head was immediately withdrawn from the hole, and the snake began to writhe in agony, rearing its head, spreading its hood, and striking wildly in all directions. "I was about to put it out of its agony by a second shot when it struck close to its own tail, and my orderly cried out that now it had bitten itself and would soon die.

Though I had clearly seen that it did not bite itself, I thought this a good opportunity of seeing whether there was any truth in the popular superstition, and if not whether I could obtain any light on the mode of its origin. The following is the result.

The snake repeatedly reared its head, and after holding it reared, struck wildly at some piece of grass or stick; twice again it struck at its own tail, and on each occasion the natives with me declared it had bitten itself. This, however, I can assert, it did not : on one occasion it stopped just short of the skin ; on the other, being apparently unable to check itself, it swerved slightly and struck the ground close alongside. It appeared to me that the snake in its agony struck wildly at the first thing that caught its eye and irritated it ; in three cases this was its own tail, but as soon as it realised what it was doing - so far from there being a deliberate attempt at suicide-it did all in its power to prevent a fatal result.

It is conceivable that, under similar circumstances, owing to loss of control over its own actions a snake might actually bite itself, and there would be wliat might pass for a well-authenticated case of suicide ; but such a case, did it ever occur, would probably be due to an accident and not to deliberate intention. I have no doubt, however, that the popular superstition finds its support in cases like that described; for the natives with me, if questioned, would reply that the snake had certainly bitten itself three times, the other apparently aimless strikes at sticks or grass having escaped their notice.

A similar explanation of the reputed suicide of scorpions was given in NATURE some time ago, but not having the file with me I cannot give the reference.

Camp near Pokran, in the Indian Desert, March 4
THE RETIREMENT OF DR. TYNDALL

$W E$ have had on more than one occasion during the last six months to refer with regret to Dr. Tyndall's impaired health brought about by overstrain. Our readers will have gathered from the daily papers during the present week that although much recruited by rest, Dr. Tyndall has yet sent in to the managers of the Royal Institution his resignation of the Chair of Natural Philosophy, which he has held since J853, and that the resignation has been accepted.

The managers and members, cordially appreciating Prof. Tyndall's services, and being anxious to mark their sense of the benefits he has conferred on the Institution during his long connexion with it, have done what was still open to them in the way of honourable recognition and regard. He has been nominated for election as Honorary Professor, a title previously borne by Sir Humphry Davy and Prof. Brande ; and one of the annual courses of lectures will be called "the Tyndall Lectures." $\mathrm{He}$ has also been requested to sit for his bust, to be placed in the Institution, in memory of his relations with it.

At the monthly meeting held last week the following letter was read :-

Hind Head, April 3, 1887

Dear Sir Frederick Bramwell, - I have halted in my reply to your letter of March 23, through sheer inability to express the feeling which the action of the managers, at their meeting on the $2 \mathrm{Ist}$, has called into life.

And my reply must now be brief, for I hardly dare trust myself to dwell upon the "resolutions" which you have conveyed to me. Taken in connexion with the severance of my life from the Royal Institution, and with the flood of memories liberated by the occasion, this plenteous kindness, this bounty of friendship, this reward so much in excess of my merits, wellnigh unmans me.

And, let me add, the noble fullness of style and expression, which I owe to yourself, and in which the good will of the managers takes corporate form, is in perfect harmony with the spirit which it enshrines.

Of the managers existent when I joined the Institution, one only remains upon the present Board. The beneficent work of many of them is for ever ended; but I do not forget the sympathy and support which they extended to me during their lives. And now the long line of kindnesses culminates in words and deeds so considerate and appreciative-so representative of their origin in true gentlemanhood and warmth of heart-that they have almost succeeded in converting into happiness the sadness of my farewell.

With heartfelt prayers for the long-continued honour and prosperity of the Institution which I have served so long, and loved so well, believe me, dear Sir Frederick, most faithfully yours,

JOHN TYNDALL

However much it may be regretted that Prof. Tyndall has felt himself compelled to withdraw from the onerous duties of a particular office, we may hope that, so far from this being a withdrawal from science itself, further leisure and rest may soon be followed by the old vigour, and that a fresh series of services may reward the labours of future years; for the work in which Profs Huxley and Tyndall have been the best known among the pioneers is not yet half accomplished.

\section{On this subject the Times writes as follows:-}

"Dr. Tyndall's name, in conjunction with that of Mr. Huxley, stands for a symbol of the nationalisation of natural science as an educational instrument. Sir Humphry Davy and Michael Faraday, in the same position, flashed the light of science into minds already prepared by leisure and cultivation to receive it. Dr. Tyndall's professorship in Albemarle Street has synchronised, and by no casual coincidence, with the recognition of the claims of the masses to be scientifically instructed. Contracted as Sir John Lubbock complains the domain of natural 
science is still among educational appliances in general, it is extraordinarily large in proportion to the place permitted it when Dr. Tyndall commenced his courses a third of a century back. Scientific truth was valued and sought by the few then as now. They themselves scarcely regarded it as a subject which concerned the rest of the community. At large the most extraordinary obtuseness prevailed. The feeble attempts to impart a little superficial information in schools and lecture-halls rendered the darkness more visible. From the Royal Institution, as from the several centres occupied at various times by Mr. Huxley, poured a continuous expostulation against popular ignorance of the very bases of physical existence. The force of the appeals lay in their tone of moral anger at an apathy represented as a degrading baseness. Their special virtue was the determination, which never flagged, to abandon nothing of the exactness of science in popularising it. Prof. Tyndall, like his constant fellow-worker, has never for an instant looked upon the masses as entitled only to second-rate knowledge. They have had it of the highest and purest which it was within his means to supply. He has admitted no distinction between esoteric and exoteric teaching. He has not put off an audience even of children with the modern equivalents for the worsted orreries and Prince Rupert's drops of elementary philosophy fifty years ago. In his hands science for the most rudimentary educational purposes has been treated as reverentially as for the most transcendental. It has walked with head as erect in the Royal Institution theatre during the Christmas holidays as at a session of the Royal Society or the British Association. The result has been that, if the country has not learnt all it might and ought, it has learnt little which it will have to unlearn. It has not been condemned to drink either scientific dregs or scientific scum."

We regard the appearance of the article from which the above quotation has been taken as one of the results of the increased appreciation of science which has followed from the crusade in which Prof. Tyndall has played so important a part, and we confess it is not without misgivings that we contemplate a future, which we trust may be a distant one, in which Prof. Tyndall's unswerving advocacy of research for its own sake, and the example of his devotion to science, unsullied by considerations of filthy lucre, are no more among us.

We believe that all the arrangements at the Institution consequent upon Prof. Tyndall's retirement are not yet completed, but we learn that Lord Rayleigh has all but agreed to take some part, at all events, of the duties of the Chair.

This will be good news to all true friends of science. The Institution has a long and noble reputation to keep or to lose. In Lord Rayleigh's hands we know it will be safe.

\section{PRIMROSES}

THE very word awakens the pleasantest memories that remain to us from the time when we almost lived in the open air and enjoyed the intense delight of plucking wild flowers without let or hindrance ; a pure and unalloyed delight actually experienced only in childhood, though it lives ever green in our hearts, and leavens the more serious pleasures of riper years. The primrose of primroses for all Britons is the wild yellow primrose that adorns woods, hedgerows, and banks from Cornwall and Sussex to the Shetlands, Orkneys, and Hebrides; for none is more lovely, though many among the endless variety spread over the north temperate and cold regions excel it in warmth and brilliancy of colouring. It is now about a year since botanists and gardeners met at South Kensington, whither they had brought their collec- tions of living plants, comprising a large number of species and varieties of Primula, solely for the purpose of seeing and talking about primroses, polyanthuses, and auriculas; and the vast amount of information contained in the report of the proceedings of those assembled merits the attention of all naturalists, to say nothing of those who love flowers merely for the pleasure they afford the eye. Being hardy, primroses were among the first plants cultivated in this country when ornamental flower-gardening began, little more than three centuries ago. The old masters-Turner, Gerard, and Parkinson-introduce us to them, the first including in his "Libellus" only the prymerose; but at that date (1538) there seems to have been no such thing in England as the cultivation of flowers for their beauty alone. Gerard's first catalogue of plants cultivated in his garden at Holborn, and published in 1596, contains "primroses, birds eies, paigles, cowslips, and beares eares": respectively Primula vulgaris, $P$. farinosa, $P$. veris, and $P$. auricula; and this is the earliest English catalogue of professedly cultivated flowers. Parkinson describes in his "Paradisus" (1629) twenty-one sorts of "beares eares" or auriculas, and he mentions that the varieties cultivated were much more numerous than he intended describing. In the report alluded to, Shirley Hibberd states that in the year 1570 many artisans, driven from the Netherlands, settled in this country, bringing with them their favourite flowers, including the best of their auriculas. Thus it would appear that the auricula was one of the very earliest "florists' flowers" cultivated in this country; and it is hardly necessary to say that it is one of the chief favourites of the present day. One of the questions discussed at the Conference was the parentage of the true auriculas and the Alpine auriculas, a question upon which florists and botanists did not quite agree; and the only way of obtaining a solution of the problem is by experiment. It is nearly certain, however, that more than one species has been concerned in the production of the various cultivated races. On the one side it has been argued that the presence of true blue is almost absolute proof that they cannot all have descended from a species having yellow flowers; and it is true that both wild and cultivated plants which exhibit great variety in the colour of their flowers rarely offer both pure blue and pure red. The china-aster (Callistephus chinensis) is an exception, but whether both colours exist in the wild plant I cannot ascertain. Philip Miller, who was the first to cultivate it in this country, states that he received seeds from France of the red and white varieties in I73I and of a blue in 1736. Amongst our native plants a very large number of those having normally blue or red flowers frequently produce white varieties; and I have myself picked red as well as white varieties of the bluebell (Scilla nutans), though it is true the red was not a very pure one. On the other hand, normally yellow flowers rarely sport into other colours.

To return to the primroses: the introduction in 1820 of the Chinese primrose added a permanently popular greenhouse flower, which is now raised by hundreds of thousands, indeed one might say millions, annually ; and almost every florist of note has his special "strains" or varieties, varying in colour from pure white to crimson, and equally in the size and cutting of the leaves and flowers, which are either double or single. The doubleflowered varieties are relatively difficult to cultivate, as they are propagated by offsets, and are less vigorous in constitution. Like the china-aster, this was unknown in a wild state until recently, when the Abbe David discovered it in the province of Hupeh.

Persons familiar only with the species of Primula hitherto mentioned can form no idea of the amount of variation exhibited by the whole genus, which embraces at least 110 distinct species, widely spread in the temperate and cold regions of the northern hemisphere, rare in 